\title{
THE USEFULNESS OF THE DEFINITIONS OF ABSTRACT NOUNS IN OALD7 AND NODE
}

\author{
MARTA GROCHOCKA \\ Adam Mickiewicz University, Poznań \\ martag@ifa.amu.edu.pl
}

\begin{abstract}
The paper presents a study aiming at comparing the usefulness of the definitions of abstract nouns in a pedagogical dictionary (Oxford Advanced Learners Dictionary, OALD7) and a nativespeaker dictionary of English (The New Oxford Dictionary of English, NODE). It starts with a brief description of the subclass of abstract nouns which is conceived of as a prototypicallystructured category composed of members exhibiting different degrees of resemblance to the prototype. Moreover, the most prototypical members of the subclass of abstract nouns are proposed and a comparison of the definitions of abstract nouns from the two dictionaries is made. The paper then reports on the empirical study which investigated the usefulness of the definitions of abstract nouns from the two dictionaries on a group of 60 dictionary users whose level of English oscillated between upper intermediate and advanced. Finally, the results of the study are discussed and an attempt is made to set out the possible reasons for the final outcome of the study.
\end{abstract}

KEYWORDS: Abstract nouns; definitions; OALD7; NODE.

\section{Abstract nouns as a prototypical category}

Cognitive linguists treat traditional word classes as prototypical categories (e.g. Taylor 2001). The cognitive look at the problem of classification of words into parts of speech carries with it certain implications with regard to the structure and organization of each word class. First and foremost, as stated by Rauh (2002), a given word class is characterized by a number of properties which are not necessarily shared by all its members. Only the best examples, or prototypes, of a given word class possess all the characteristic properties of that class. This stands in sharp contrast to the classical, i.e. Aristotelian, view on categories, according to which all the members of a category must share a fixed set of necessary and sufficient features. In addition, the boundaries between the classes are fuzzy, just like in the case of prototypical cognitive categories, with smooth transitions at their borders. To illustrate this point, Rauh (2002) provides the example of letter 
and write, which, as maximally distinct, represent best examples of the categories noun and verb respectively, as opposed to writing in he is fond of writing, which is a peripheral member of the noun class, as it shares properties of both word classes.

This cognitive perspective on the status of word classes seems to be valid also when applied to the subclass of abstract nouns. Regarding the subclass of abstract nouns as having a prototypical structure implies that some abstract nouns constitute better examples of their category than others. Another consequence stemming from the cognitive approach as regards the class of abstract nouns is that the dichotomy between concrete and abstract nouns should be viewed as a continuum or scale, ranging from nouns which are very abstract to those which are very concrete (Svensson 1998: 180). The main ramification of adopting this perspective is that some criteria must be established for creating a list of abstract nouns, owing to the fact that the borderline between the two extremes is fuzzy.

\section{The most prototypical abstract nouns}

The problems that I have encountered when deciding on the criteria for selection while establishing a list of abstract nouns were legion. The definitions of the notion of abstract noun as found in grammar books were too obscure and imprecise for the practical purpose of establishing some criteria that would enable me to decide whether a given noun should be treated as abstract or not. Nevertheless, as a point of departure, I collected a few definitions of the notion of abstract noun which are presented in Table 1 in the Appendix. These definitions gave me an idea about the possible kinds of abstract nouns that can be distinguished. It seems that when it comes to the semantic criteria for determining the abstract noun class membership, the most representative members of the category denote:

- feelings/emotions;

- qualities;

- states;

- ideas/concepts;

- events.

What is more, any doubts as to whether to treat a given noun as abstract or not were dissipated when the noun in question fulfilled the formal criterion of ending in one of the (abstract) noun-forming suffixes shown in Table 2 in the Appendix.

One of the difficulties stems from the fact that many nouns have both a concrete and an abstract meaning, for instance deverbal nouns very often denote both the action and the result of this action (Arnold 1986: 123), e.g. publication may refer to the process of printing a book or the result of this process, i.e. the book itself. In the case of nouns which have distinct senses due to such metonymic alternations, the more abstract 
sense concerning a process or an action is chosen to be included in the subclass of abstract nouns. In addition, I exclude generic words, such as animal or vehicle, since their reference is still much more concrete than that of such prototypical abstract nouns as freedom or beauty. Furthermore, I distinguish between abstract nouns per se (those which denote exclusively abstract concepts that cannot be observed or measured) and concrete nouns which are used in a figurative fashion and in consequence refer to abstractions as well. Consider the following example: in the Longman Dictionary of Current English (LDOCE4), we find that the first sense of the noun baby is 'a very young child who has not yet learned to speak or walk', which means that the noun in question is undeniably a very concrete one, as it denotes a person. The seventh sense of baby in LDOCE4 reads as follows: 'something special that someone has developed or is responsible for'. This sense of the noun baby, which is signposted in the dictionary as "responsibility", makes its reference, in fact, quite abstract. Nevertheless, it is important to realize that this subsense is a result of using the core meaning of the noun in a figurative way. The same applies to many other words, for instance backbone (literal meaning: 'spine'; figurative use: 'the most important part of an organization or group of people' or 'courage and determination') or fabric (literal: 'cloth used for making clothes, curtains etc; [= material]'; figurative: the fabric of society - 'its basic structure, way of life, relationships, and traditions').

Summing up, the notion of abstract noun is very problematic. To the best of my knowledge, no comprehensive classification of abstract nouns has as yet been proposed. According to Michael (1970: 299), philosophically the distinction between "material" and "immaterial" was "either trivial or too difficult to be relevant to the grammarian". I am quite convinced that the latter is the case.

\section{The comparison of the definitions of abstract nouns from OALD7 and NODE}

Having determined the abstract noun class membership, I can proceed to check how abstract nouns are defined in dictionaries. The purpose of this analysis is to examine the similarities and differences in the treatment of abstract nouns in two dictionaries: a monolingual learner's dictionary and a dictionary primarily aimed at native speakers of English. The dictionaries which have been chosen as the objects of investigation are the seventh edition of Oxford Advanced Learner's Dictionary (henceforth, OALD7) and the first edition of The New Oxford Dictionary of English (henceforth, NODE). The underlying assumption is that since the two dictionaries are addressed to two different groups of users, each with their own specific needs, they will consequently differ in the language of explanation. Since my interest is exclusively in definitions, I will ignore all the other respects in which the two dictionary types differ, such as the treatment of pronunciation, examples of usage, or register and field labels.

For the sake of comparing the abstract noun definitions in the two above-mentioned dictionaries, 94 abstract nouns were selected (according to the criteria laid out in section 
2) from a dictionary other than the two objects of comparison, namely the fourth edition of Longman Dictionary of Contemporary English (LDOCE4). The number of abstract nouns from each letter was roughly proportionate to the number of pages a given letter occupies in the dictionary. Definitions of these nouns, both from OALD7 and NODE, are presented in Table 3 in the Appendix. While looking for the similarities and differences between the definitions, the following factors were taken into consideration:

(i) complexity of language (simple or difficult wording of definitions?);

(ii) syntax (complex, unnatural syntactic constructions?);

(iii) length of definitions (lengthy definitions discouraging to read?);

(iv) type of definitions (analytic definition? synonymous equivalent?);

(v) perspective from which the definition is written (anthropocentric or referentbased?).

The most obvious difference between a monolingual learner's dictionary and a dictionary for native speakers is that definitions found in dictionaries designed for learners should be written in a simpler language than those in dictionaries for the mother-tongue market. However, simpler definitions tend to be more wordy than definitions consisting of more challenging but succinct words (Kirkpatrick 1985: 10). As expected, definitions from NODE are generally shorter but the language of definitions tends to be more difficult in comparison with OALD7. The number of words in the definitions of 76 randomly selected nouns from OALD7 and NODE were counted. Mean definition length for the OALD7 sample is 13.75 words ( $\mathrm{SD}=6.23, \mathrm{~N}=76$ ), compared to 11.93 words $(\mathrm{SD}=6.86, \mathrm{~N}=76)$ for NODE definitions. Thus, an average OALD7 definition is nearly two words (or 15\%) longer than the corresponding definition in NODE. This difference is statistically significant in a pair-wise t-test $(\mathrm{T}=2.57, \mathrm{df}=150, \mathrm{p}=0.013)$. For instance, abandon is defined in NODE as 'complete lack of inhibition or restraint' whereas in OALD7 it is defined as 'an uncontrolled way of behaving that shows that sb does not care what other people think'. The obvious advantage of the NODE definition is its brevity (only six words as opposed to sixteen words in the corresponding definition from OALD7). Nevertheless, words such as inhibition and restraint may be unknown and cause problems to the dictionary user.

It also happens that the definition from NODE is actually longer than the corresponding definition from OALD7, but these are exceptional cases. For instance, racism in NODE is defined as 'the belief that all members of each race possess characteristics, abilities, or qualities specific to that race, especially so as distinguish it as inferior or superior to another race or races'. It is a lengthy definition which may be discouraging to read. On the contrary, the definition from OALD7 is shorter and much more userfriendly: 'the belief that some races of people are better than others'. This definition is brief, simple and pertinent.

Apart from the general tendency for being longer, definitions from OALD7 are sometimes obscure, which is a consequence of using simple words. As a case in point, 
the lengthy definition of dare: 'something dangerous, difficult or embarrassing that you try to persuade sb to do, to see if they will do it', seems to be quite vague when juxtaposed with the succinct and straightforward definition from NODE: 'a challenge, especially to prove courage'. Furthermore, the definition from OALD7 has also a more complex syntax. The use of the abbreviation for somebody and then the pronoun they may be quite confusing. By and large, understanding the definition from OALD7 may constitute quite a challenge for the dictionary user. The following OALD7 definition of sacrifice also constitutes a good example illustrating how the desire to make the defining language simple takes its toll on the definition's syntax, making it more complex and unnatural: 'the fact of giving up sth important or valuable to you in order to get or do sth that seems more important; sth that you give up in this way'. The awkwardness becomes even more apparent when juxtapose this definition with the definition from NODE: 'an act of giving up something valued for the sake of something else regarded as more important or worthy'.

Some definitions from the two dictionaries are of comparable length but differ to a great extent with regard to the words used to define. For example, abhorrence in OALD7 is defined as 'a feeling of strong hatred, especially for moral reasons' whereas in NODE its definition reads as follows: 'a feeling of revulsion; disgusted loathing'. The key term contributing most to grasping the meaning of the noun in the OALD7 definition is hatred, which is a frequent word $(21,500,000$ hits on Google) in comparison with the key terms from the NODE definition: revulsion (1,710,000 hits on Google) and loathing $(5,970,000$ hits on Google) which are relatively less frequent items, and thus more likely not to be known to the dictionary user.

As for the types of definitions used by the two dictionaries, in the sample selected for analysis all the definitions are analytical ones. The analytical definition specifies the meaning of a lexical item by means of genus proximum and differentia specifica. The genus term provides us with information concerning the class of things to which a given word belongs, and the differentia determines characteristic features of this word, enabling us to distinguish it from all the other members of the class. NODE also sometimes provides synonymous equivalents.

Some consistency can be observed when it comes to the differences between definitions from OALD7 and NODE, that is to say the definitions differ with respect to the perspective they are written from. The OALD7 definitions tend to be anthropocentric definitions, which, in general terms, means that they are written from the perspective of a person. This makes them similar to folk defining (Nakamoto 1998: 206). By contrast, the NODE definitions are always referent-based, which means that they define the definiendum from the perspective of the entity to which they refer. As a case in point, consider the following NODE definition of tactic: 'an action or strategy carefully planned to achieve a specific end'. The definition of tactic from OALD7 is clearly an anthropocentric one: 'the particular method you use to achieve sth', as is signalled by the second person pronoun. 
On the whole, unsuprisingly, the language of explanation of the two dictionaries differs considerably. However, in order to find out which definitions are more useful to learners, an empirical study needs to be carried out.

\section{The study}

The aim of the study is to investigate whether the definitions of abstract nouns in a pedagogical dictionary (OALD7) are more useful for learners than definitions found in a native-speaker dictionary (NODE). The assumption that definitions from a pedagogical dictionary are as useful for learners as definitions from a native-speaker dictionary was adopted as the null hypothesis.

\subsection{Subjects}

The number of subjects that took part in the study was 60 . All of the subjects were high school students in their second year. They were native speakers of Polish at the upper intermediate and advanced levels of proficiency in English. Their level of proficiency was established on the basis of the level of handbooks the students used in class. Additionally, teachers were consulted about their students' proficiency level.

\subsection{Materials}

In order to be able to compare the usefulness of definitions from the two dictionaries, a test was created. It consisted of sixteen abstract nouns and their definitions, eight of which were taken from NODE, and the other eight from OALD7. The order of nouns in any given test was randomized. To make all the definitions uniform, labels indicating synonyms that appear in the definitions from OALD were replaced by semicolons. Attention was paid to selecting only difficult items which upper intermediate and advanced learners are unlikely to know so that their previous knowledge would not influence the completion of the task. The test was prepared in two versions: the nouns that were accompanied by a definition from NODE in version 1 were provided with definitions from OALD7 in version 2, and vice versa. In addition, each version was prepared in two formats which differed only in the order of items (see Table 4 in the Appendix for OALD7 and NODE definitions of nouns that appeared in the test, and Table 5 for one of the versions of the test). Each subject did one format of the test. Thanks to such a design it was possible to minimize the effect of the learner variable as well as the effect of item, i.e. the possible discrepancies in the levels of difficulty of items (Lew and Dziemianko 2006: 233). 


\subsection{Pilot study}

A pilot study was administered in which eight subjects took part. Half of the subjects were given version 1 of the test, and the other half were provided with version 2 . The task was the same as in the study proper, however, the list of abstract nouns was different. In the pilot study the test included aberration, pageantry and backlash, which were subsequently replaced with abandon, camaraderie and panache. The rationale behind replacing aberration with another item is that there is a grapho-phonemic equivalent of aberration in Polish, i.e. aberracja, which is semantically analogical to the English noun. However, it is a difficult Polish word and there is a possibility that the subjects could provide correct equivalents without knowing the actual meaning of the word, or even without reading its definition. In order to avoid such a situation, aberration was excluded from the test. When it comes to pageantry and backlash, they were removed as not suitable for the purposes of the experiment because in Polish two-word equivalents of these words are required: the PWN-Oxford English-Polish Dictionary (PWNOE) gives wielka gala as the meaning of pageantry, and gwattowna reakcja or ostry sprzeciw as the equivalents for backlash. The New Kościuszko Foundation English-Polish Dictionary (NKFD) even provides a three-word equivalent: petne przepychu widowisko for pageantry, and gwaltowny sprzeciw (wobec czegoś), or gwaltowna reakcja negatywna (na coś) as the equivalents for backlash. The subjects were asked to provide only one-word equivalents for the English abstract nouns so as to avoid the possibility of paraphrasing or translating parts of the definitions on the part of the subjects. This could have been quite a probable scenario, since trying to synthesise information found in a definition in order to come up with a one-word equivalent appears to be a much more demanding task, requiring much more mental effort than a simple paraphrase or translation. Hence, nouns such as pageantry or backlash did not constitute the best candidates to be included in the test. In addition, in the tests used in the pilot study the noun chosen to act as an example to be followed was abnegation. Again, it was an unfortunate choice for two reasons. Firstly, just like in the case of aberration, there is a grapho-phonemic Polish equivalent for abnegation, i.e. abnegacja (NKFD). Secondly, the meaning of abnegation can be rendered in Polish in a simpler way, but more than one word is needed for this purpose. The possible equivalents are: wyrzeczenie się, zrzeczenie się (PWNOE), or poświęcenie się dla innych (NKFD). For these reasons, abnegation was replaced by justice (in Polish sprawiedliwość) which seems a better candidate for serving as an example. Last but not least, one more significant change was made after the pilot study. Initially, the subjects were allotted twenty five minutes to complete the task. It turned out that this amount of time was much too long, as most of the subjects managed to complete the task in about fifteen minutes. Obviously, this was taken into consideration in the study proper. 


\subsection{Procedure}

The subjects were asked to do a test which consisted in providing one-word Polish equivalents for English abstract nouns drawing on their definitions. It was a decoding task in that the subjects were supposed to decipher the meaning of an English noun after reading its definition, and an encoding task in that they were to give a one-word Polish equivalent of this noun. The instructions were provided in written form, at the top of the test page (see Table 5 in the Appendix). They were also supplied orally by the experimenter. ${ }^{1}$ Below the instructions an example was provided: the abstract noun justice, its definition, and the Polish equivalent: sprawiedliwość. Towards the end of the experiment, the subjects were asked to circle those nouns whose meanings and Polish equivalents had been familiar to them before. The experiment was designed for approximately 15 minutes and was conducted during regular class time.

\subsection{Scoring}

A score of 1 was attributed to any correct Polish equivalent (for the possible correct Polish equivalents see Table 6 in the Appendix). In the cases of incorrect equivalents and lack of equivalents a score of 0 was assigned. When an item was familiar to the subject and was marked with a circle, its equivalent was given a score of 1 , provided that it was correct. However, in some cases the subject marked an item as known, but supplied a wrong equivalent. Obviously, such responses were attributed the score of 0 . It needs to be added that very few subjects happened to have known the nouns in advance. And even if they claimed to have been familiar with a given noun, it turned out that they only thought they knew the word, as they frequently provided incorrect equivalents. The responses were checked against Polish equivalents of the abstract nouns taken from various bilingual dictionaries including PWNOE, NKFD, and Collins English-Polish Dictionary (CS). Also, a dictionary of synonyms was sometimes consulted. Nonetheless, in a few instances it was not obvious whether a given equivalent should be treated as correct or not. In such problematic cases, another native speaker of Polish was consulted and a uniform decision was reached. Equivalents belonging to parts of speech other than the noun were marked as incorrect and given a score of 0 . Furthermore, when two equivalents were provided, the response was treated as correct with the proviso that the two equivalents were close synonyms. Finally, equivalents that were semantically appropriate but did not fit the register of the English noun were regarded as correct and given a score of 1 due to the fact that the definitions were provided without register labels.

\footnotetext{
${ }^{1}$ It was always me who acted as the experimenter.
} 


\subsection{Results}

Overall accuracy rates for successful provision of Polish equivalents on the basis of definitions from NODE and OALD7 are presented in Figure 1. As can be seen in the figure, the subjects were more successful in providing correct Polish equivalents for English abstract nouns accompanied by definitions from OALD7 (47.25\%) than for nouns whose definitions were taken from NODE (39.75\%). Definitions from OALD7 proved more useful for learners than definitions from NODE by $18.78 \%$. An Analysis of Variance (ANOVA) showed that the difference between the equivalent accuracy rates for definitions from the two dictionaries is statistically significant $(p=0.014)$.

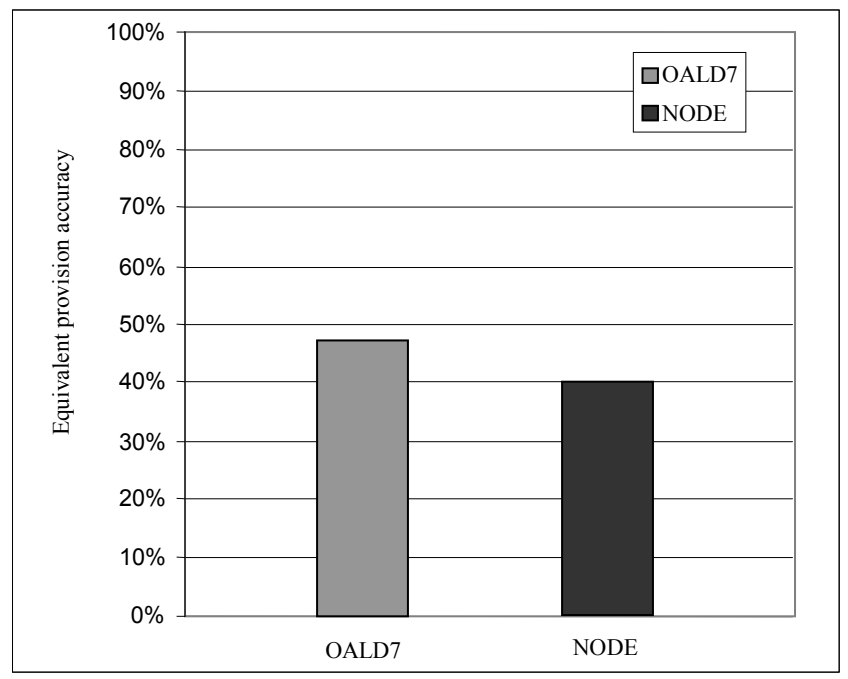

Figure 1. Mean equivalent provision accuracy for OALD7 and NODE.

More detailed results are shown in Figure 2 which presents the distribution of correct equivalents, correct equivalents to nouns already known by the subjects, lack of equivalents and incorrect equivalents (for exact figures see Table 7 in the Appendix). In the case of definitions from OALD, the subjects provided 215 (out of 480) correct equivalents, which constitutes $44.79 \%$. For comparison, the definitions from NODE yielded 181 (out of 480) correct equivalents, which amounts to $37.7 \%$.

It is noteworthy that individual items differed considerably in their rates of successful equivalent provision, as can be observed from Figure 3. Not even one correct equivalent was given for abandon, whereas as many as $26(86.7 \%)$ correct equivalents in the case of definitions from NODE and $24(80 \%)$ in the case of definitions from OALD7 were provided for calamity. 

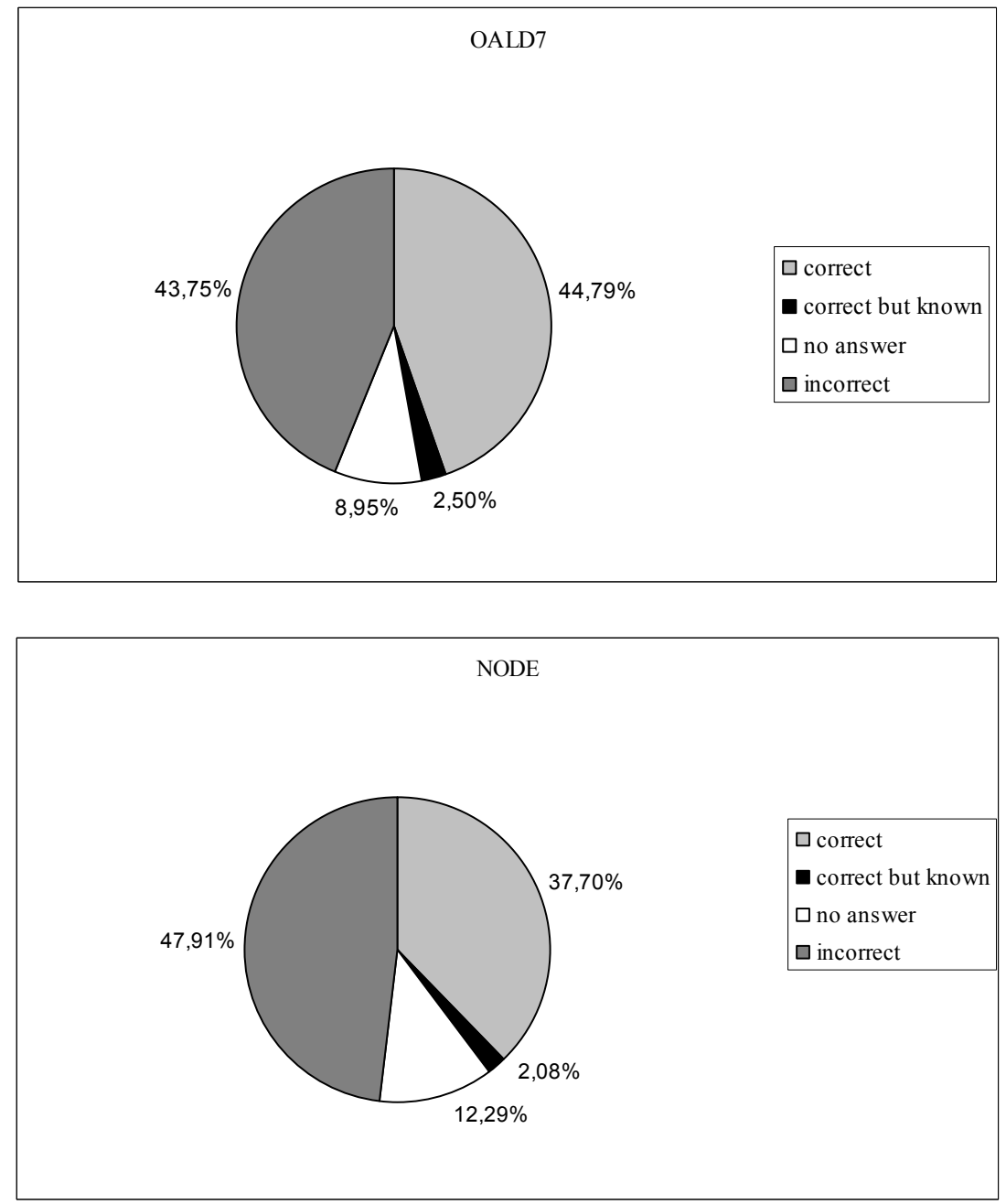

Figure 2. A comparison of the results for OALD7 and NODE. ${ }^{2}$

Interestingly, the definitions from NODE were more frequently left with no equivalent provided (59 cases, i.e. 12.29\%) than those from OALD7 (43 cases, i.e. 8.95\%). The number of lacking equivalents for individual items is presented in Figure 4. Incorrect equivalents were provided in 210 (out of 480) cases for the OALD7 definitions and in 230 cases for the NODE definitions, which translates into $43.5 \%$ and $47.91 \%$ respectively.

\footnotetext{
${ }^{2}$ Exact numbers instead of percentages are given in Table 7 in the Appendix.
} 


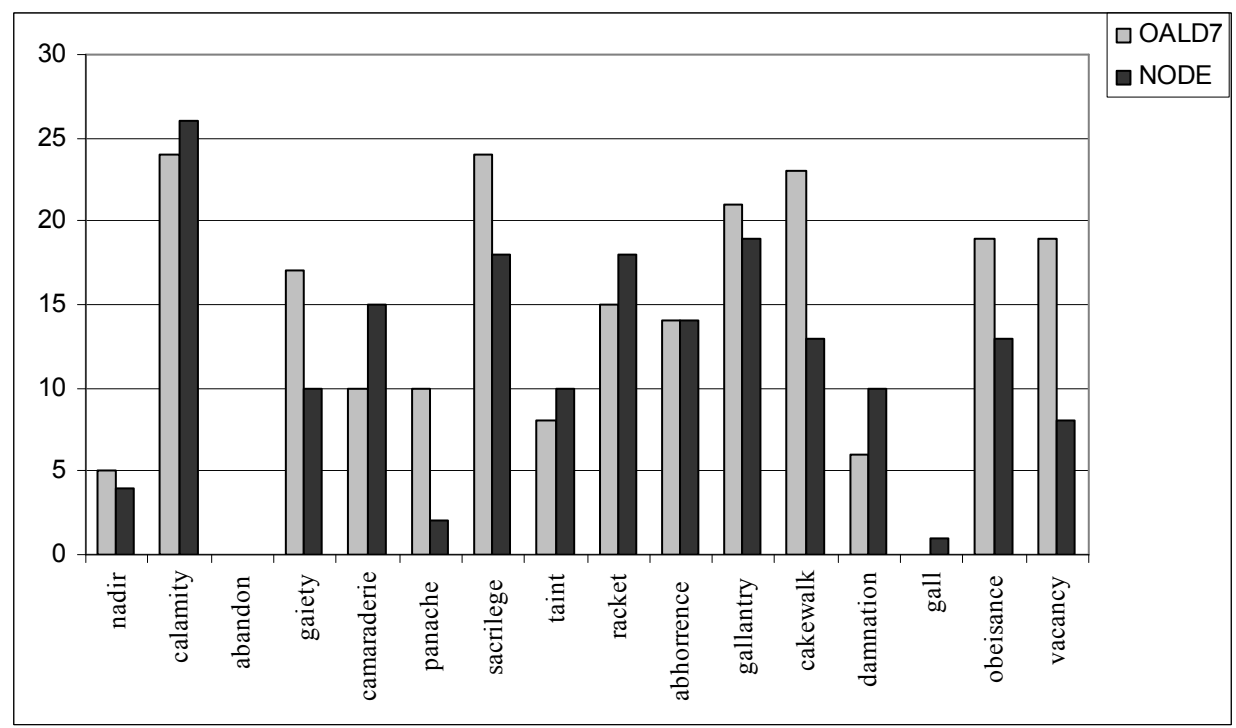

Figure 3. The number of correct equivalents for individual items.

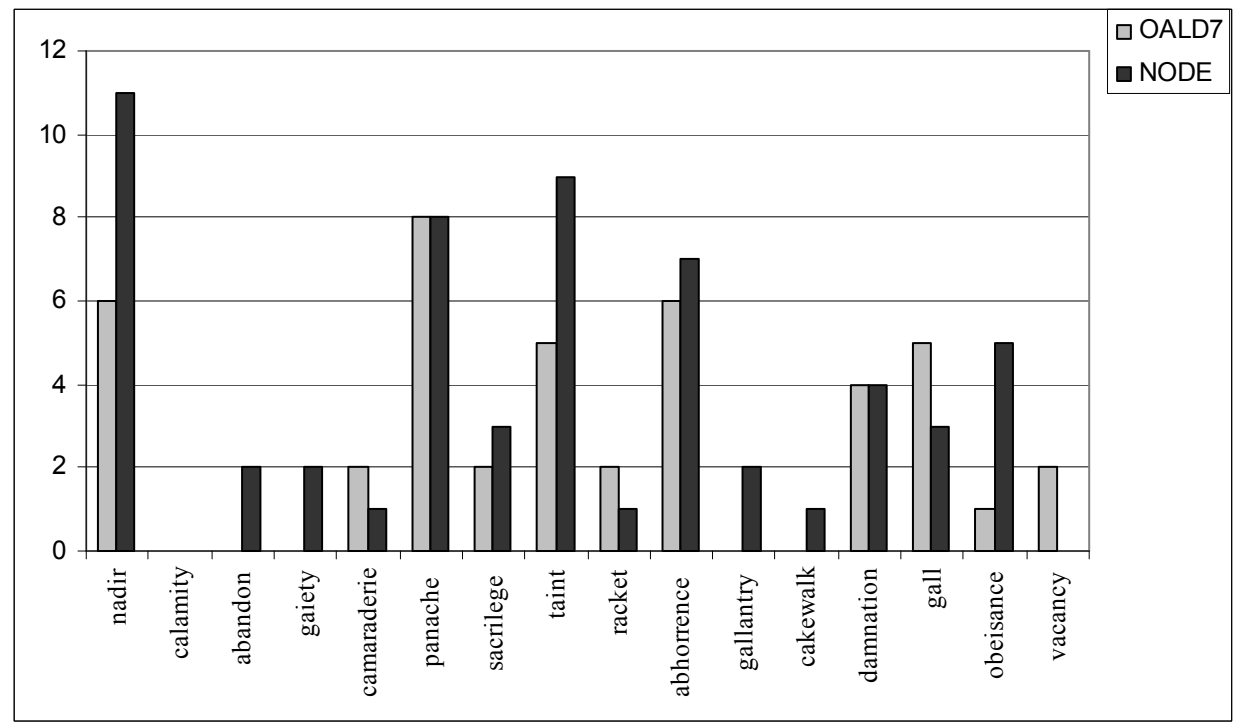

Figure 4. The number of lacking equivalents for individual items. 


\subsection{Discussion and conclusions}

A more careful qualitative analysis of the students' answers revealed hints as to the possible reasons for the results of the study being what they are.

First of all, it seems that a lot of mistakes in providing correct equivalents stemmed from using what Miller and Gildea (1985, as quoted in Nesi 2000: 43) ${ }^{3}$ refer to as the Kidrule strategy. This strategy refers to the type of mistakes that learners make when using a dictionary. In general terms, it consists in paying attention to familiar words and phrases within a definition and ignoring other segments of the definition which are phrased in difficult language, and thus cause problems with comprehension. In consequence, instead of deciphering the meaning of the unknown word from the whole definition, the learner treats the meaning of the familiar word or segment within a definition as the meaning of the word being defined.

Coming back to the study, it appears that some of the mistakes in the subjects' responses can be explained by means of the Kidrule strategy. The instances of applying the Kidrule strategy by the subjects are more numerous for the definitions from NODE than for the definitions from OALD7. This may be the result of the fact that definitions from the native-speaker dictionary are phrased in much more difficult language. For instance, in NODE we can find the following definition of sacrilege: 'violation or misuse of what is regarded as sacred'. The Polish equivalent should be either świętokradztwo or profanacja. The number of incorrect answers for this particular item was eight (out of a total of thirty). Within these eight improper responses for sacrilege, three were the result of following the Kidrule strategy and concentrating only on the familiar words within the definition: naruszenie (a result of taking violation to be the meaning of sacrilege), nadużycie (due to concentrating on misuse), and świętość (as a consequence of paying attention to sacred and totally ignoring the remaining part of the definition). The last case most clearly illustrates the possible dangers of the Kidrule strategy at work since świętość 'sanctity' means something quite the opposite to what sacrilege means. It is noteworthy that subjects working with the definition of sacrilege from OALD7 ('an act of treating a holy thing or place without respect'), which is worded in a relatively simple vocabulary, gave only three wrong equivalents, none of which resulted from the application of the Kidrule strategy. Two more telling examples of the consequences of using the Kidrule strategy when coping with definitions from NODE include: taint ('a trace of a bad or undesirable quality or substance') translated as substancja ('substance'), and racket ('an illegal or dishonest scheme for obtaining money') translated as

\footnotetext{
${ }^{3}$ In their study, Miller and Gildea (1988) asked 10-11-year-old children, who were native speakers of English, to look up certain words in a dictionary, and then compose sentences incorporating these words. One of the findings of the study was that unacceptable sentences created by children were frequently written in accordance with the strategy which consisted in spotting a familiar word or phrase within a definition, creating a sentence incorporating this familiar segment, and then replacing the segment with the target word. This finding is relevant in the context of my study as it is possible that adult non-native speakers' behaviour may be similar to what English-speaking children do when dealing with difficult definitions (Nesi 2000: 78).
} 
plan ('scheme'). Subjects who dealt with the corresponding definitions from OALD7, which nota bene are again relatively simpler, did not make mistakes that could be ascribed to using the Kidrule strategy. Nevertheless, in the two aforementioned examples the subjects dealing with the NODE definitions provided more correct equivalents than the subjects who worked with the OALD7 definitions. For taint accompanied by the NODE definition, there were eight correct equivalents provided, as opposed to ten correct equivalents when taint was paired with the OALD7 definition. As for racket, there were fifteen correct equivalents for the OALD7 definition and eighteen correct equivalents for the NODE definition. Hence, in these two cases the mistakes caused by the application of the Kidrule strategy did not constitute the decisive factor that would determine the results and contribute to the OALD7 definitions having advantage over the NODE definitions. This is probably because the difference in the level of difficulty between the definitions of taint and racket in OALD7 and NODE (see Table 4 in the Appendix) is not so significant as in the case of definitions for sacrilege, and therefore some factors, other than the application of the Kidrule strategy, must have influenced the shape of the results.

Summing up, the conclusion to be drawn from the above observations is probably that "hard" words used in definitions from NODE may have promoted the application of the Kidrule strategy. This would help to explain why there were more instances of incorrect equivalents resulting from resorting to the Kidrule strategy for the NODE definition of sacrilege, which is worded in a more challenging language than the corresponding definition from OALD7. Of course, though it seems plausible, it is only a hypothesis that needs to be checked empirically.

A closer examination of the incorrect responses also points to the possibility that the subjects approached and used some of the definitions in a way which Müllich calls the "sham" use of a dictionary (Müllich 1990, as quoted in Nesi 2000: 40). This phenomenon occurs when the dictionary user does not manage to assimilate new and unexpected information that he or she finds in a dictionary but instead reads only part of the definition to confirm a preconceived notion concerning the word's meaning. Alternatively, the dictionary user may deviate from the information found in a definition due to putting an erroneous interpretation on it or filtering it through personal associations (Müllich 1990, as quoted in Nesi 2000: 40). I have reasons to suspect that some of the subjects in my study made a "sham" use of the definitions at least in a few cases.

For example, one third of the subjects, i.e. ten of them, provided opuszczenie 'abandonment' as the equivalent of abandon when it was accompanied by the definition from NODE, out of which seven subjects marked the word as already known. ${ }^{4}$ It seems to me that the subjects did not read the whole definition of abandon, or they did not read the definition carefully enough, or probably they did not even care to read the definition at all, especially when they thought they knew the noun beforehand. Instead, they relied on their previous knowledge concerning the meaning of the verb abandon. This precon-

\footnotetext{
${ }^{4}$ For the definitions of abandon from OALD7 and NODE see Table 4 in the Appendix.
} 
ceived idea led them into believing that the meaning of the noun is derivative from the meaning of the verb. That would provide an explanation for the subjects providing wrong equivalents for the noun whose meaning they claimed to have already been familiar with. All in all, preconceptions about the meaning of a seemingly known word may prevent the subjects from assimilating information provided in the definition, or they may even lead to disregarding pieces of information that conflict with the student's preconceived notions concerning the meaning of the word (Nesi 2000: 105), as has happened in the case of abandon.

In the cases where abandon was paired with the definition from OALD7, none of the responses was correct, just like in the case of abandon being provided with the definition form NODE. But interestingly, the equivalents given by the subjects confronted with the OALD7 definition were very diverse in comparison with the responses obtained from the NODE definition. The Polish equivalents: (z)lekceważenie 'disrespect', olewanie which is a very informal word for 'disregard', and egoizm 'selfishness' appeared 3 times each, opuszczenie 'abandonment' was given 2 times, two subjects provided no equivalents at all, and the rest of the equivalents were remarkably diverse and totally inadequate to the meaning of abandon. To illustrate their variety, let me provide a few of them: arogancja 'arrogance', apatia 'apathy', samolubność 'selfishness', lekkomyślność 'recklessness', ignorancja 'ignorance', nierozwaga 'foolhardiness', znieczulica 'callousness', szaleństwo 'madness', dezercja 'desertion', indywidualizm 'individualism', nonszalancja 'nonchalance', obojętnośc 'indifference'. As can be seen from the diversity of the responses, the OALD definition of abandon failed completely in explaining the meaning of the word. What is more, it turned out to be very misleading in that it led the subjects to come up with equivalents that had absolutely nothing in common with the word's meaning.

The case of abandon is interesting for one more reason. It was the only abstract noun in the test for which not a single subject managed to provide a correct equivalent irrespective of the dictionary from which the definition was provided. In PWNOE, we find that the noun abandon means zapamietanie, oddanie sie, and that it appears in the phrase: to do sth with gay abandon, in Polish oddawać się czemuś z radościa. According to NKFD, the equivalents of abandon may be pasja, żywiolowość, zapamiętanie (sie). NKFD also gives us the phrase: with (gay/wild) abandon and its meaning: impulsywnie, zapamiętale. CS provides the meaning of abandon only as part of phrases: with abandon - bez opamiętania, and with joyous abandon - w radosnym uniesieniu. After consulting these bilingual dictionaries, it becomes apparent that the word is problematic as it occurs in phrases and it is not easy to provide its equivalent when the word is in isolation. The English noun phrase can even be translated into Polish as an adverb.

On the whole, in the case of abandon neither of the two dictionaries managed to fulfill its role and comply with the users' needs. Ideally, a monolingual dictionary should be able to provide answers to all the questions about words that the dictionary user may ask. Put differently, the needs, expectations, and limitations of the dictionary user should always be taken into consideration. Nonetheless, the problem is that the 
lexicographer cannot know in advance what questions the dictionary user is going to ask (Hanks 2006). This is probably what happened in the case of abandon. The lexicographer writing the definition for abandon to be included in a dictionary for international audience was not able to predict that Polish dictionary users will have problems with this particular item. It seems that in this case a bilingual dictionary or an example of usage would be of much more help to a person wanting to get to know the meaning of abandon.

\subsection{Some methodological considerations}

I decided to base my study on a test on experimental subjects rather than a questionnaire because information obtained in this fashion is more objective and reliable. Notwithstanding the obvious merits of test-based investigation into dictionary use and dictionary requirements, the method is not devoid of limitations. The most serious problem is that it is often difficult to mark tests objectively and analyse data (Nesi 2000:32). No wonder I found it problematic to decide how to treat certain responses, especially when they constituted borderline cases whose correctness was a matter of degree. Since the checking for accuracy was subjective to some extent, it was indispensable to consult an independent reader. Furthermore, I sometimes found it difficult to think of the possible reasons for the results of the study being as they are. In addition, one more serious flaw of experimental studies is that the tasks and conditions are artificial as they do not reflect normal circumstances of the dictionary consultation process (Dziemianko and Lew 2006: 217). Obviously, the task given to the subjects in my study was arbitrary as well. In natural circumstances, the dictionary user may come across the word abandon in some context, and with the help of this context as well as the dictionary definition, he or she might be able to come up with a correct mother-tongue equivalent of the word and the dictionary definition would not turn out to be completely useless. Moreover, there is a possibility that the subject might have understood a given definition but failed to provide an equivalent because he or she could not think of a one-word Polish equivalent in the artificial test conditions or within the time permitted. What is more, the quantity of use constitutes an important factor that may affect the test results (Nesi 2000: 32). There is a possibility that some subjects might use one of the dictionaries on regular basis, for instance at home. In consequence, such a subject may be used to the defining style of the dictionary, and thus perform significantly better when dealing with definitions from the familiar dictionary. Whether the subjects were used to using a monolingual or a bilingual dictionary, or both, is also a crucial factor. Therefore, to make the study more reliable, probably the subjects should also have been given a questionnaire aiming at establishing a more detailed profile of this group. Probably such information would be helpful in gaining a deeper understanding of the results of the study.

Last but not least, it is noteworthy that NODE is not a typical native-speaker dictionary since it was written with the aim of making its definitions simpler and more 
user-friendly. In this respect it is similar to a learner's dictionary. Nevertheless, the study revealed that the definitions from NODE, a dictionary for native speakers, are comparatively more difficult to comprehend for learners than the definitions from OALD7, a typical learner's dictionary. These findings corroborate an intuitive feeling that since OALD7 is designed for learners, it should prove more useful than a nativespeaker dictionary. It would be interesting to check whether this difference would be higher when instead of NODE, a more typical native-speaker dictionary was taken as the object of comparison. This, however, remains a topic for further investigation.

\section{REFERENCES}

Dictionaries

Cambridge advanced learner's dictionary on CD-ROM [CALD]. 2003. (1st edition.) Cambridge: Cambridge University Press.

Dictionary.com.

$<$ http://dictionary.reference.com/browse/abstract\%20noun> (Date of access: 16 Jan 2007.)

Fisiak, J. (ed.). 1996. Collins słownik angielsko-polski, polsko-angielski [Collins English-Polish and Polish-English dictionary]. (Vol. 1: English-Polish [CS].) Warszawa: HarperCollins Publishers - Polska Oficyna Wydawnicza BGW.

Fisiak, J. (ed.). 2003. The new Kosciuszko Foundation dictionary [NKFD]. (Vol. 1: EnglishPolish.) New York: The Kosciuszko Foundation - Universitas.

Linde-Usiekniewicz, J. (ed.). 2002. PWN-Oxford wielki słownik angielsko-polski [PWN-Oxford English-Polish dictionary; PWNOE]. Warszawa: Państwowe Wydawnictwo Naukowe.

Pearsall, J. (ed.). 1998. The new Oxford dictionary of English [NODE]. Oxford: Oxford University Press.

Random House Webster's electronic dictionary and thesaurus, college edition on CD-ROM [RHW] 1994. Random House Inc.

Simpson, J.A. and E.S.C. Weiner (eds.). 2000. (2nd edition). The Oxdord English dictionary [OED]. Oxford: Clarendon Press.

Sinclair, J. (ed.). 2003. Collins Cobuild advanced learner's English dictionary. Glasgow: HarperCollins Publishers.

Summers, D. (ed.). 2005. Longman dictionary of contemporary English [LDOCE4]. (4th edition with Writing Assisstant.) Harlow: Longman.

Using English.com. $<$ http://www.usingenglish.com/glossary/abstract-noun.html $>$ (Date of access: 7 Jan 2007.)

Wehmeier, S. (ed.). 2005. Oxford advanced learner's dictionary [OALD7]. (7th edition.) Oxford: Oxford University Press.

$<$ http://www.oup.com/elt/catalogue/ teachersites/oald7/?cc= global $>$ (Date of access: 16 Jan 2007.)

Your dictionary.com

$<$ http://www.yourdictionary.com/ahd/a/a0029350.html $>$ (Date of access: 17 Jan 2007.) 
Other works

Arnold, I.V.. 1986. The English Word. Moskva: Vysshaya Shkola.

Dziemianko, A. and R. Lew. 2006. "Research into dictionary use by Polish learners of English: Some methodological considerations". In: Dziubalska-Kołaczyk, K. (ed.), IFAtuation: A life in IFA. A festschrift for Professor Jacek Fisiak on the occasion of his 70th birthday. Poznan: Wydawnictwo Naukowe Uniwersytetu Adama Mickiewicza. 211-233.

Hanks, P. 2006. "English monolingual lexicography". $<$ http://ucnk.ff.cuni.cz/doc/English_Monolingual_Lexicography.ppt $>$ (Date of access: 16 May 2007.)

Kirkpatrick, B. 1985. "A lexicographical dilemma: monolingual dictionaries for the native speaker and for the learner". In: Ilson, R.F. (ed.), Dictionaries, lexicography and language learning. Oxford: Pergamon Press. 7-13.

Lew, R. and A. Dziemianko. 2006. "A new type of folk-inspired definition in English monolingual learners' dictionaries and its usefulness for conveying syntactic information". International Journal of Lexicography 19(3). 225-242.

Michael, I. 1970. English grammatical categories and the tradition to 1800. London: Cambridge University Press.

Miller, G.A. and P.M. Gildea. 1985. "How to misread a dictionary". AILA Bulletin 1985. 13-26.

Müllich, H. 1990. “Die Definition ist blöd!” Herübersetzen mit dem einsprachigen Wörterbuch. Das französische und englische Lernerwörterbuch in der Hand der deutschen Schüler. Tübingen: Niemeyer.

Nakamoto, K. 1998. "From which perspective does the definer define the definiendum: Anthropocentric or referent-based?" International Journal of Lexicography 11. 205-218.

Nesi, H. 2000. The use and abuse of EFL dictionaries: How learners of English as a foreign language read and interpret dictionary entries. (Lexicographica Series Maior 98.) Tübingen: Niemeyer.

Rauh, G. 2002. "Word classes as prototypical categories". In: Scholz, S., M. Klages, E. Hanston and U. Römer (eds.), Language: Context and cognition: Papers in honour of Wolf-Dietrich Bald's 60th birthday. München: Langenscheidt-Longman. 259-270.

Svensson, P. 1998. Number and countability in English nouns: An embodied model. Uppsala: Swedish Science Press.

Taylor, J.R. 2001. Kategoryzacja w języku [Linguistic categorization.] (Translated by Anna Skucińska.) Kraków: Universitas. 


\section{APPENDIX}

Table 1. Definitions of the notion of abstract noun. ${ }^{5}$

\begin{tabular}{ll}
\hline LDOCE4 & $\begin{array}{l}\text { A noun that names a feeling, quality, or state rather than an object, } \\
\text { animal, or person. For example, 'hunger' and 'beauty' are abstract } \\
\text { nouns. }\end{array}$ \\
\hline Collins & $\begin{array}{l}\text { In grammar, an abstract noun refers to a quality or idea rather than } \\
\text { to a physical object. } \\
\text {... abstract words such as glory, honor, and courage. }\end{array}$ \\
\hline A noun which refers to a thing which does not exist as a material \\
object: \\
'Happiness', 'honesty' and 'liberty' are abstract nouns.
\end{tabular}

Table 2. Abstract noun-forming suffixes (adapted from Arnold 1986: 48-57).

\begin{tabular}{lll}
\hline Nominal stems & Verbal stems & Adjectival stems \\
\hline -age bondage & -age breakage & -dom freedom \\
-dom serfdom & -ance/-ence guidance/ & -ism realism \\
-hood childhood & reference & -ity/-ty reality, cruelty \\
-ics linguistics & -ion/-tion/-ation oppression, & -ness goodness, \\
-ism heroism & action, liberation & loneliness \\
-ship friendship & -ment embarrassment & \\
\hline
\end{tabular}

\footnotetext{
${ }^{5}$ Items in bold are emphasised by myself.
} 
Table 3. Definitions of abstract nouns from OALD7 and NODE.

\begin{tabular}{|c|c|c|}
\hline Abstract noun & OALD7 & NODE \\
\hline abandon & $\begin{array}{l}\text { an uncontrolled way of behaving } \\
\text { that shows that sb does not care } \\
\text { what other people think }\end{array}$ & $\begin{array}{l}\text { complete lack of inhibition or re- } \\
\text { straint }\end{array}$ \\
\hline aberration & $\begin{array}{l}\text { a fact, an action or a way of be- } \\
\text { having that is not usual, and that } \\
\text { may be unacceptable }\end{array}$ & $\begin{array}{l}\text { a departure from what is normal, } \\
\text { usual, or expected, typically one } \\
\text { that is unwelcome } \\
\text { Subsense: a departure from some- } \\
\text { one's usual moral character or } \\
\text { mental ability, typically for the } \\
\text { worse }\end{array}$ \\
\hline abhorrence & $\begin{array}{l}\text { a feeling of strong hatred, espe- } \\
\text { cially for moral reasons }\end{array}$ & $\begin{array}{l}\text { a feeling of revulsion; disgusted } \\
\text { loathing }\end{array}$ \\
\hline ability & $\begin{array}{l}\text { 1. the fact that } \mathrm{sb} / \mathrm{sth} \text { is able to do } \\
\text { sth } \\
\text { 2. a level of skill or intelligence }\end{array}$ & $\begin{array}{l}\text { the capacity to do something } \\
\text { talent that enables someone to } \\
\text { achieve a great deal }\end{array}$ \\
\hline abnegation & $\begin{array}{l}\text { the act of not allowing yourself to } \\
\text { have sth that you want; the act of } \\
\text { rejecting sth }\end{array}$ & $\begin{array}{l}\text { the action of renouncing or reject- } \\
\text { ing something } \\
\text { Subsense: self-denial }\end{array}$ \\
\hline babyhood & $\begin{array}{l}\text { the period of your life when you } \\
\text { are a baby }\end{array}$ & $\begin{array}{l}\text { no separate entry, put under baby } \\
\text { as a derivative }\end{array}$ \\
\hline background & $\begin{array}{l}\text { 1. the details of a person's family, } \\
\text { education, experience etc. } \\
\text { 2. the circumstances or past events } \\
\text { which help explain why sth is how } \\
\text { it is; information about these }\end{array}$ & $\begin{array}{l}\text { the general scene, surroundings, or } \\
\text { circumstances } \\
\text { Subsense: a person's education, } \\
\text { experience, and social circum- } \\
\text { stances }\end{array}$ \\
\hline backing & help SYN support & help or support \\
\hline backlash & $\begin{array}{l}\text { a strong negative reaction by a } \\
\text { large number of people, for exam- } \\
\text { ple to sth that has recently changed } \\
\text { in society }\end{array}$ & $\begin{array}{l}\text { a strong and adverse reaction by a } \\
\text { large number of people, especially } \\
\text { to a social or political develop- } \\
\text { ment }\end{array}$ \\
\hline backslapping & $\begin{array}{l}\text { loud and enthusiastic behaviour } \\
\text { when people are praising each } \\
\text { other for sth good they have done }\end{array}$ & $\begin{array}{l}\text { the action of slapping a person's } \\
\text { back in congratulation or encour- } \\
\text { agement } \\
\text { Subsense: the action of congratu- } \\
\text { lating someone, typically as a } \\
\text { mere gesture or in return for fa- } \\
\text { vours }\end{array}$ \\
\hline backst & $\begin{array}{l}\text { the action of criticizing sb when } \\
\text { they are not there, while pretend- } \\
\text { ing to be their friend at other times }\end{array}$ & $\begin{array}{l}\text { the action or practice of criticizing } \\
\text { someone in a treacherous manner } \\
\text { while feigning friendship }\end{array}$ \\
\hline
\end{tabular}




\begin{tabular}{|c|c|c|}
\hline cachet & $\begin{array}{l}\text { if sth has cachet, it has a special } \\
\text { quality that people admire and ap- } \\
\text { prove of SYN prestige }\end{array}$ & $\begin{array}{l}\text { the state of being respected or ad- } \\
\text { mired; prestige }\end{array}$ \\
\hline cakewalk & $\begin{array}{l}\text { something that is extremely easy } \\
\text { to do }\end{array}$ & $\begin{array}{l}\text { an absurdly or surprisingly easy } \\
\text { task }\end{array}$ \\
\hline calamity & $\begin{array}{l}\text { an event that causes great damage } \\
\text { to people's lives, property, etc. } \\
\text { SYN disaster }\end{array}$ & $\begin{array}{l}\text { an event causing great and often } \\
\text { sudden damage or distress; a dis- } \\
\text { aster }\end{array}$ \\
\hline calculation & $\begin{array}{l}\text { 1. the act or process of using num- } \\
\text { bers to find out an amount } \\
\text { 2. the process of using your } \\
\text { judgement to decide what the re- } \\
\text { sults would be of doing sth } \\
\text { 3. careful planning for yourself } \\
\text { without caring about other people }\end{array}$ & $\begin{array}{l}\text { a mathematical determination of } \\
\text { the size or number of something } \\
\text { Subsense: (often calculations) an } \\
\text { assessment of the risks, possibili- } \\
\text { ties, or effects of a situation or } \\
\text { course of action }\end{array}$ \\
\hline calibre & $\begin{array}{l}\text { the quality of sth, especially a per- } \\
\text { son's ability SYN standard }\end{array}$ & $\begin{array}{l}\text { the quality of someone's character } \\
\text { or the level of their ability } \\
\text { Subsense: the standard reached by } \\
\text { something }\end{array}$ \\
\hline calligraphy & $\begin{array}{l}\text { beautiful handwriting that you do } \\
\text { with a special pen or brush; the art } \\
\text { of producing this }\end{array}$ & $\begin{array}{l}\text { decorative handwriting or } \\
\text { handwritten lettering } \\
\text { Subsense: the art of producing } \\
\text { decorative handwriting or lettering } \\
\text { with a pen or brush }\end{array}$ \\
\hline calling & $\begin{array}{l}\text { 1. a strong desire or feeling of duty } \\
\text { to do a particular job, especially } \\
\text { one in which you help other peo- } \\
\text { ple SYN vocation } \\
\text { 2. a profession or career }\end{array}$ & $\begin{array}{l}\text { a strong urge towards a particular } \\
\text { way of life or career; a vocation } \\
\text { Subsense: a profession or occupa- } \\
\text { tion }\end{array}$ \\
\hline calm & $\begin{array}{l}\text { 1. a quiet and peaceful time or } \\
\text { situation } \\
\text { 2. a quiet and relaxed manner }\end{array}$ & $\begin{array}{l}\text { the absence of violent or confron- } \\
\text { tational activity within a place or } \\
\text { group } \\
\text { Subsense: the absence of nervous- } \\
\text { ness, agitation, or excitement in a } \\
\text { person }\end{array}$ \\
\hline damage & $\begin{array}{l}\text { 1. physical harm caused to sth } \\
\text { which makes it less attractive, use- } \\
\text { ful or valuable } \\
\text { 2. harmful effects on sb/sth }\end{array}$ & $\begin{array}{l}\text { physical harm caused to something } \\
\text { in such a way as to impair its } \\
\text { value, usefulness, or normal func- } \\
\text { tion. } \\
\text { Subsense: unwelcome and detri- } \\
\text { mental effects }\end{array}$ \\
\hline damnation & $\begin{array}{l}\text { the state of being in hell; the act of } \\
\text { sending sb to hell }\end{array}$ & $\begin{array}{l}\text { condemnation to eternal punish- } \\
\text { ment in hell }\end{array}$ \\
\hline
\end{tabular}




\begin{tabular}{|c|c|c|}
\hline dance & $\begin{array}{l}\text { 1. a series of movements and steps } \\
\text { that are usually performed to mu- } \\
\text { sic; a particular example of these } \\
\text { movements and steps } \\
\text { 2. the art of dancing, especially for } \\
\text { entertainment } \\
\text { 3. an act of dancing } \\
\text { 4. a social event at which people } \\
\text { dance } \\
\text { 5. a piece of music for dancing to }\end{array}$ & $\begin{array}{l}\text { a series of steps and movements } \\
\text { that match the speed and rhythm } \\
\text { of a piece of music } \\
\text { Subsense: a particular sequence of } \\
\text { steps and movements constituting } \\
\text { a particular form of dancing } \\
\text { Subsense: steps and movements of } \\
\text { this type considered as an activity } \\
\text { or art form } \\
\text { Subsense: a social gathering at } \\
\text { which people dance } \\
\text { Subsense: a set of lively move- } \\
\text { ments resembling a dance } \\
\text { Subsense: a piece of music for } \\
\text { dancing to } \\
\text { Subsense: (also dance music) mu- } \\
\text { sic for dancing to, especially in a } \\
\text { club }\end{array}$ \\
\hline danger & $\begin{array}{l}\text { 1. the possibility of sth happening } \\
\text { that will injure, harm or kill sb, or } \\
\text { damage or destroy sth } \\
\text { 2. the possibility of sth bad or un- } \\
\text { pleasant happening } \\
\text { 3. a person or thing that may cause } \\
\text { damage, or harm sb }\end{array}$ & $\begin{array}{l}\text { the possibility of suffering harm or } \\
\text { injury } \\
\text { Subsense: the possibility of some- } \\
\text { thing unwelcome or unpleasant }\end{array}$ \\
\hline$\overline{\text { dare }}$ & $\begin{array}{l}\text { something dangerous, difficult or } \\
\text { embarrassing that you try to per- } \\
\text { suade sb to do, to see if they will } \\
\text { do it }\end{array}$ & $\begin{array}{l}\text { a challenge, especially to prove } \\
\text { courage }\end{array}$ \\
\hline eagerness & $\begin{array}{l}\text { eager adj. } \\
\text { very interested and excited by sth } \\
\text { that is going to happen or about } \\
\text { sth that you want to do SYN keen } \\
\text { Derivative: eagerness }\end{array}$ & $\begin{array}{l}\text { eager adj. } \\
\text { (of a person) wanting to do or } \\
\text { have something very much } \\
\text { Derivative: eagerness }\end{array}$ \\
\hline earner & $\begin{array}{l}\text { 1. a person who earns money for a } \\
\text { job that they do } \\
\text { 2. an activity or a business that } \\
\text { makes a profit }\end{array}$ & $\begin{array}{l}\text { Subsense: an activity or product } \\
\text { that brings in income of a speci- } \\
\text { fied kind or level }\end{array}$ \\
\hline ease & $\begin{array}{l}\text { 1. lack of difficulty } \\
\text { 2. the state of feeling relaxed or } \\
\text { comfortable without worries, prob- } \\
\text { lems or pain }\end{array}$ & $\begin{array}{l}\text { absence of difficulty or effort } \\
\text { Subsense: freedom from worries } \\
\text { or problems, especially about } \\
\text { one's material situation }\end{array}$ \\
\hline eccentricity & $\begin{array}{l}\text { 1. behaviour that people think is } \\
\text { strange or unusual; the quality of } \\
\text { being unusual and different from } \\
\text { other people } \\
\text { 2. an unusual act or habit }\end{array}$ & the quality of being eccentric \\
\hline
\end{tabular}




\begin{tabular}{|c|c|c|}
\hline fabrication & $\begin{array}{l}\text { fabricate verb } \\
\text { 1. to invent false information in } \\
\text { order to trick people SYN make up } \\
\text { 2. to make or produce goods, } \\
\text { equipment, etc. from various dif- } \\
\text { ferent materials SYN manufacture } \\
\text { Derivative: fabrication }\end{array}$ & $\begin{array}{l}\text { fabricate verb } \\
\text { invent or concoct (something), } \\
\text { typically with deceitful intent } \\
\text { Derivative: fabrication }\end{array}$ \\
\hline facet & $\begin{array}{l}\text { 1. a particular part or aspect of sth } \\
\text { 2. one of the flat sides of a jewel }\end{array}$ & $\begin{array}{l}\text { one side of something many-sided, } \\
\text { especially of a cut gem } \\
\text { Subsense: a particular aspect or } \\
\text { feature of something }\end{array}$ \\
\hline facetiousness & $\begin{array}{l}\text { facetious adj. } \\
\text { trying to appear amusing and } \\
\text { intelligent at a time when other } \\
\text { people do not think it is } \\
\text { appropriate, and when it would be } \\
\text { better to be serious SYN flippant } \\
\text { Derivative: facetiousness }\end{array}$ & $\begin{array}{l}\text { facetious adj. } \\
\text { treating serious issues with delib- } \\
\text { erately inappropriate humour; flip- } \\
\text { pant } \\
\text { Derivative: facetiousness }\end{array}$ \\
\hline facileness & $\begin{array}{l}\text { facile adj. } \\
\text { 1. produced without effort or care- } \\
\text { ful thought SYN glib } \\
\text { 2. obtained too easily and having } \\
\text { little value } \\
\text { NO facileness }\end{array}$ & $\begin{array}{l}\text { facile adj. } \\
\text { 1. (especially of a theory or argu- } \\
\text { ment) appearing neat and compre- } \\
\text { hensive only by ignoring the true } \\
\text { complexities of an issue; superfi- } \\
\text { cial } \\
\text { Subsense: (of a person) having a } \\
\text { superficial or simplistic knowl- } \\
\text { edge or approach } \\
\text { 2. (of success, especially in sport) } \\
\text { easily achieved; effortless } \\
\text { Derivative: facileness }\end{array}$ \\
\hline facilitation & $\begin{array}{l}\text { facilitate verb } \\
\text { to make an action or a process } \\
\text { possible or easier } \\
\text { Derivative: facilitation }\end{array}$ & the action of facilitating something \\
\hline gaiety & $\begin{array}{l}\text { the state of being cheerful and full } \\
\text { of fun }\end{array}$ & $\begin{array}{l}\text { the state or quality of being light- } \\
\text { hearted or cheerful }\end{array}$ \\
\hline gain & $\begin{array}{l}\text { 1. an increase in the amount of sth, } \\
\text { especially in wealth or weight } \\
\text { 2. an advantage or improvement } \\
\text { 3. financial profit }\end{array}$ & an increase in wealth or resources \\
\hline gall & $\begin{array}{l}\text { 1. rude behaviour showing a lack } \\
\text { of respect that is surprising be- } \\
\text { cause the person doing it is not } \\
\text { embarrassed SYN impudence } \\
2 \text {. a bitter feeling full of hatred } \\
\text { SYN resentment }\end{array}$ & bold, impudent behaviour \\
\hline
\end{tabular}




\begin{tabular}{|c|c|c|}
\hline gallantry & $\begin{array}{l}\text { 1. courage, especially in a battle } \\
2 \text {. polite attention given by men to } \\
\text { women }\end{array}$ & $\begin{array}{l}\text { courageous behaviour, especially } \\
\text { in battle } \\
\text { polite attention or respect given by } \\
\text { men to women }\end{array}$ \\
\hline habit & $\begin{array}{l}\text { 1. a thing that you do often and } \\
\text { almost without thinking, especially } \\
\text { sth that is hard to stop doing } \\
\text { 2. usual behaviour }\end{array}$ & $\begin{array}{l}\text { a settled or regular tendency or } \\
\text { practice, especially one that is hard } \\
\text { to give up }\end{array}$ \\
\hline habitation & $\begin{array}{l}\text { 1. the act of living in a place } \\
\text { 2. a place where people live }\end{array}$ & $\begin{array}{l}\text { the state or process of living in a } \\
\text { particular place }\end{array}$ \\
\hline haematology & $\begin{array}{l}\text { the scientific study of the blood } \\
\text { and its diseases }\end{array}$ & $\begin{array}{l}\text { the study of the physiology of the } \\
\text { blood }\end{array}$ \\
\hline haemophilia & $\begin{array}{l}\text { a medical condition that causes } \\
\text { severe loss of blood from even a } \\
\text { slight injury because the blood } \\
\text { fails to clot normally. It usually af- } \\
\text { fects only men although it can be } \\
\text { passed on by women. }\end{array}$ & $\begin{array}{l}\text { a medical condition in which the } \\
\text { ability of the blood to clot is se- } \\
\text { verely reduced, causing the suf- } \\
\text { ferer to bleed severely from even a } \\
\text { slight injury. The condition is typi- } \\
\text { cally caused by a hereditary lack } \\
\text { of coagulation factor, most often } \\
\text { factor VIII }\end{array}$ \\
\hline iconoclasm & $\begin{array}{l}\text { iconoclastic adj. } \\
\text { criticizing popular beliefs or estab- } \\
\text { lished customs and ideas } \\
\text { Derivative: iconoclasm }\end{array}$ & $\begin{array}{l}\text { 1. the action of attacking or asser- } \\
\text { tively rejecting cherished beliefs } \\
\text { and institutions or established val- } \\
\text { ues and practices } \\
\text { 2. the rejection or destruction of } \\
\text { religious images as heretical; the } \\
\text { doctrine of iconoclasts }\end{array}$ \\
\hline iconography & $\begin{array}{l}\text { the use or study of images or sym- } \\
\text { bols in art }\end{array}$ & $\begin{array}{l}\text { the use or study of images or sym- } \\
\text { bols in visual arts } \\
\text { Subsense: the visual images, sym- } \\
\text { bols, or modes of representation } \\
\text { collectively associated with a per- } \\
\text { son, cult or movement } 2 \text {. the illus- } \\
\text { tration of a subject by drawings or } \\
\text { figures }\end{array}$ \\
\hline jailbreak & $\begin{array}{l}\text { an escape from prison, usually by } \\
\text { several people }\end{array}$ & an escape from jail \\
\hline karaoke & $\begin{array}{l}\text { a type of entertainment in which a } \\
\text { machine plays only the music of } \\
\text { popular songs so that people can } \\
\text { sing the words themselves }\end{array}$ & $\begin{array}{l}\text { [mass noun] a form of entertain- } \\
\text { ment, offered typically by bars and } \\
\text { clubs, in which people take turns } \\
\text { to sing popular songs into a mi- } \\
\text { crophone over pre-recorded back- } \\
\text { ing tracks }\end{array}$ \\
\hline labour & $\begin{array}{l}\text { 1. work, especially physical work } \\
\text { 2. a task or period of work }\end{array}$ & $\begin{array}{l}\text { work, especially hard physical } \\
\text { work }\end{array}$ \\
\hline
\end{tabular}




\begin{tabular}{|c|c|c|}
\hline lack & $\begin{array}{l}\text { the state of not having sth or not } \\
\text { having enough of sth SYN dearth, } \\
\text { shortage }\end{array}$ & $\begin{array}{l}\text { the state of being without or not } \\
\text { having enough of something }\end{array}$ \\
\hline lamentation & $\begin{array}{l}\text { an expression of great sadness or } \\
\text { disappointment }\end{array}$ & $\begin{array}{l}\text { Derivative under: lament }(\mathrm{n})=\mathrm{a} \\
\text { passionate expression of grief or } \\
\text { sorrow }\end{array}$ \\
\hline machinery & $\begin{array}{l}\text { the organization or structure of } \\
\text { sth; the system for doing sth }\end{array}$ & $\begin{array}{l}\text { the organization or structure of } \\
\text { something or for doing something }\end{array}$ \\
\hline machismo & $\begin{array}{l}\text { aggressive male behaviour that } \\
\text { emphasizes the importance of be- } \\
\text { ing strong rather than being intel- } \\
\text { ligent and sensitive }\end{array}$ & $\begin{array}{l}\text { strong or aggressive masculine } \\
\text { pride }\end{array}$ \\
\hline macramé & $\begin{array}{l}\text { the art of tying knots in string in a } \\
\text { decorative way, to make things }\end{array}$ & $\begin{array}{l}\text { the art of knotting cord or string in } \\
\text { patterns to make decorative articles }\end{array}$ \\
\hline macrocosm & $\begin{array}{l}\text { any large complete structure that } \\
\text { contains smaller structures, for ex- } \\
\text { ample the universe - compare mi- } \\
\text { crocosm }\end{array}$ & $\begin{array}{l}\text { the universe; the cosmos } \\
\text { Subsense: the whole of a complex } \\
\text { structure, especially as represented } \\
\text { or epitomized in a small part of it- } \\
\text { self (a microcosm) }\end{array}$ \\
\hline $\begin{array}{l}\text { macroeconom- } \\
\text { ics }\end{array}$ & $\begin{array}{l}\text { the study of large economic sys- } \\
\text { tems, such as those of whole coun- } \\
\text { tries or areas of the world }\end{array}$ & $\begin{array}{l}\text { the part of economics concerned } \\
\text { with large-scale or general eco- } \\
\text { nomic factors, such as interest } \\
\text { rates and national productivity }\end{array}$ \\
\hline nadir & $\begin{array}{l}\text { the worst moment of a particular } \\
\text { situation }\end{array}$ & $\begin{array}{l}\text { the lowest point in the fortunes of } \\
\text { a person or organization }\end{array}$ \\
\hline naivety & $\begin{array}{l}\text { naive adj. } \\
\text { 1. lacking experience of life, } \\
\text { knowledge or good judgement and } \\
\text { willing to believe that people al- } \\
\text { ways tell you the truth } \\
\text { 2. (of people and their behaviour) } \\
\text { innocent and simple SYN artless } \\
\text { Derivative: naivety }\end{array}$ & $\begin{array}{l}\text { lack of experience, wisdom, or } \\
\text { judgement } \\
\text { Subsense: innocence or unsophis- } \\
\text { tication }\end{array}$ \\
\hline obduracy & $\begin{array}{l}\text { obdurate adj. } \\
\text { refusing to change your mind or } \\
\text { your actions in any way SYN } \\
\text { stubborn } \\
\text { Derivative: obduracy } \\
\end{array}$ & $\begin{array}{l}\text { obdurate adj. } \\
\text { stubbornly refusing to change } \\
\text { one's opinion or course of action } \\
\text { Derivative: obduracy }\end{array}$ \\
\hline obedience & $\begin{array}{l}\text { obedient adj. } \\
\text { doing what you are told to do; } \\
\text { willing to obey } \\
\text { Derivative: obedience }\end{array}$ & $\begin{array}{l}\text { compliance with someone's } \\
\text { wishes or orders or acknowledge- } \\
\text { ment of their authority } \\
\underline{\text { Subsense: submission to a law or }} \\
\text { rule } \\
\underline{\text { Subsense: observance of a monas- }} \text { tic rule }\end{array}$ \\
\hline
\end{tabular}




\begin{tabular}{|c|c|c|}
\hline obeisance & $\begin{array}{l}\text { 1. respect for sb/sth or willingness } \\
\text { to obey sb } \\
\text { 2. the act of bending your head or } \\
\text { the upper part of your body in or- } \\
\text { der to show respect for sb/sth }\end{array}$ & deferential respect \\
\hline pacifism & $\begin{array}{l}\text { the belief that war and violence are } \\
\text { always wrong }\end{array}$ & $\begin{array}{l}\text { the belief that war and violence are } \\
\text { unjustifiable and that all disputes } \\
\text { should be settled by peaceful } \\
\text { means }\end{array}$ \\
\hline package & $\begin{array}{l}\text { (also package deal) a set of items } \\
\text { or ideas that must be bought or ac- } \\
\text { cepted together }\end{array}$ & $\begin{array}{l}\text { (also package deal) a set of pro- } \\
\text { posals or terms offered or agreed } \\
\text { as a whole }\end{array}$ \\
\hline paederasty & $\begin{array}{l}\text { pederast noun } \\
\text { a man who has sex with a boy } \\
\text { Derivative: pederasty }\end{array}$ & $\begin{array}{l}\text { sexual activity involving a man } \\
\text { and a boy }\end{array}$ \\
\hline paediatrics & $\begin{array}{l}\text { the branch of medicine concerned } \\
\text { with children and their diseases }\end{array}$ & $\begin{array}{l}\text { the branch of medicine dealing } \\
\text { with children and their diseases }\end{array}$ \\
\hline pageant & $\begin{array}{l}\text { 1. a public entertainment in which } \\
\text { people dress in historical costumes } \\
\text { and give performances of scenes } \\
\text { from history } \\
\text { 2. a competition for young women } \\
\text { in which their beauty, personal } \\
\text { qualities and skills are judged: a } \\
\text { beauty pageant - compare beauty } \\
\text { contest } \\
\text { 3. something that is considered as } \\
\text { a series of interesting and different } \\
\text { events }\end{array}$ & $\begin{array}{l}\text { a public entertainment consisting } \\
\text { of a profession of people in elabo- } \\
\text { rate, colourful costumes, or an } \\
\text { outdoor performance of a histori- } \\
\text { cal scene } \\
\text { Subsense: a thing that looks } \\
\text { impressive or grand, but is actually } \\
\text { shallow and empty } \\
\text { Subsense: historical - a scene } \\
\text { erected on a fixed stage or moving } \\
\text { vehicle as a public show } \\
\text { Subsense: a beauty contest }\end{array}$ \\
\hline pageantry & $\begin{array}{l}\text { impressive and exciting events and } \\
\text { ceremonies involving a lot of peo- } \\
\text { ple wearing special clothes }\end{array}$ & elaborate display or ceremony \\
\hline pagination & $\begin{array}{l}\text { the process of giving a page num- } \\
\text { ber to each page of a book; the } \\
\text { page numbers given }\end{array}$ & $\begin{array}{l}\text { the sequence of numbers assigned } \\
\text { to pages in a book or periodical }\end{array}$ \\
\hline pain & $\begin{array}{l}\text { 1. the feelings that you have in } \\
\text { your body when you have been } \\
\text { hurt or when you are ill/sick } \\
\text { 2. mental or emotional suffering }\end{array}$ & $\begin{array}{l}\text { physical suffering or discomfort } \\
\text { caused by illness or injury } \\
\text { Subsense: a feeling of marked dis- } \\
\text { comfort in a particular part of the } \\
\text { body } \\
\text { Subsense: mental suffering or dis- } \\
\text { tress }\end{array}$ \\
\hline rabies & $\begin{array}{l}\text { a disease of dogs and other ani- } \\
\text { mals that causes madness and } \\
\text { death. Infected animals can pass }\end{array}$ & $\begin{array}{l}\text { a contagious and fatal viral disease } \\
\text { of dogs and other mammals, } \\
\text { transmissible through the saliva to }\end{array}$ \\
\hline
\end{tabular}




\begin{tabular}{|c|c|c|}
\hline & $\begin{array}{l}\text { the disease to humans by biting } \\
\text { them }\end{array}$ & $\begin{array}{l}\text { humans and causing madness and } \\
\text { convulsions. Also called HY- } \\
\text { DROPHOBIA }\end{array}$ \\
\hline racism & $\begin{array}{l}\text { 1. the unfair treatment of people } \\
\text { who belong to a different race; } \\
\text { violent behaviour towards them } \\
\text { 2. the belief that some races of } \\
\text { people are better than others }\end{array}$ & $\begin{array}{l}\text { the belief that all members of each } \\
\text { race possess characteristics, abili- } \\
\text { ties, or qualities specific to that } \\
\text { race, especially so as distinguish it } \\
\text { as inferior or superior to another } \\
\text { race or races. } \\
\text { Subsense: prejudice, discrimina- } \\
\text { tion, or antagonism directed } \\
\text { against someone of a different race } \\
\text { based on such a belief }\end{array}$ \\
\hline racket & $\begin{array}{l}\text { a dishonest or illegal way of get- } \\
\text { ting money }\end{array}$ & $\begin{array}{l}\text { an illegal or dishonest scheme for } \\
\text { obtaining money }\end{array}$ \\
\hline radiology & $\begin{array}{l}\text { the study and use of different types } \\
\text { of radiation in medicine, for ex- } \\
\text { ample to treat diseases }\end{array}$ & $\begin{array}{l}\text { the science dealing with X-rays } \\
\text { and other high-energy radiation, } \\
\text { especially the use of such radiation } \\
\text { for the diagnosis and treatment of } \\
\text { disease }\end{array}$ \\
\hline radiotherapy & $\begin{array}{l}\text { the treatment of disease by radia- } \\
\text { tion }\end{array}$ & $\begin{array}{l}\text { the treatment of disease, especially } \\
\text { cancer, using X-rays or similar } \\
\text { forms of radiation }\end{array}$ \\
\hline sabotage & $\begin{array}{l}\text { 1. the act of doing deliberate dam- } \\
\text { age to equipment, transport, ma- } \\
\text { chines, etc. to prevent an enemy } \\
\text { from using them, or to protest } \\
\text { about sth } \\
\text { 2. the act of deliberately spoiling } \\
\text { sth in order to prevent it from be- } \\
\text { ing successful }\end{array}$ & the action of sabotaging something \\
\hline sacredness & $\begin{array}{l}\text { sacred adj. } \\
\text { 1. connected with God or a god; } \\
\text { considered to be holy } \\
\text { 2. very important and treated with } \\
\text { great respect SYN } \text { sacrosanct } \\
\text { Derivative: sacredness }\end{array}$ & $\begin{array}{l}\text { sacred adj. } \\
\text { connected with God (or the gods) } \\
\text { or dedicated to a religious purpose } \\
\text { and so deserving veneration } \\
\text { Subsense: regarded with great re- } \\
\text { spect and reverence by a particular } \\
\text { religion, group, or individual } \\
\text { Derivative: sacredness }\end{array}$ \\
\hline sacrifice & $\begin{array}{l}\text { 1. the fact of giving up sth impor- } \\
\text { tant or valuable to you in order to } \\
\text { get or do sth that seems more im- } \\
\text { portant; sth that you give up in this } \\
\text { way } \\
\text { 2. the act of offering sth to a god, }\end{array}$ & $\begin{array}{l}\text { an act of slaughtering an animal or } \\
\text { person or surrendering a posses- } \\
\text { sion as an offering to God or to a } \\
\text { divine or supernatural figure } \\
\text { Subsense: an animal, person, or } \\
\text { object offered in this way }\end{array}$ \\
\hline
\end{tabular}




\begin{tabular}{|c|c|c|}
\hline & $\begin{array}{l}\text { especially an animal that has been } \\
\text { killed in a special way; an animal, } \\
\text { etc. that is offered in this way }\end{array}$ & $\begin{array}{l}\text { Subsense: an act of giving up } \\
\text { something valued for the sake of } \\
\text { something else regarded as more } \\
\text { important or worthy. }\end{array}$ \\
\hline sacrilege & $\begin{array}{l}\text { an act of treating a holy thing or } \\
\text { place without respect }\end{array}$ & $\begin{array}{l}\text { violation or misuse of what is re- } \\
\text { garded as sacred }\end{array}$ \\
\hline sadism & $\begin{array}{l}\text { 1. enjoyment from watching or } \\
\text { making sb suffer } \\
\text { 2. a need to hurt sb in order to get } \\
\text { sexual pleasure-compare maso- } \\
\text { chism }\end{array}$ & $\begin{array}{l}\text { the tendency to derive pleasure, } \\
\text { especially sexual gratification, } \\
\text { from inflicting pain, suffering, or } \\
\text { humiliation on others. } \\
\text { Subsense: (in general use) deliber- } \\
\text { ate cruelty }\end{array}$ \\
\hline sadness & $\begin{array}{l}\text { 1. the feeling of being sad } \\
\text { 2. something which makes you sad }\end{array}$ & $\begin{array}{l}\text { sad adj. } \\
\text { feeling or showing sorrow; un- } \\
\text { happy } \\
\text { Subsense: causing or characterized } \\
\text { by sorrow or regret; unfortunate } \\
\text { and regrettable. } \\
\text { Derivative: sadness }\end{array}$ \\
\hline sadomasochism & $\begin{array}{l}\text { enjoyment from hurting sb and be- } \\
\text { ing hurt, especially during sexual } \\
\text { activity }\end{array}$ & $\begin{array}{l}\text { psychological tendency or sexual } \\
\text { practice characterised by both sa- } \\
\text { dism and masochism. }\end{array}$ \\
\hline safeguard & $\begin{array}{l}\text { something that is designed to pro- } \\
\text { tect people from harm, risk or dan- } \\
\text { ger }\end{array}$ & $\begin{array}{l}\text { a measure, such as a law or proce- } \\
\text { dure, designed to prevent some- } \\
\text { thing undesirable }\end{array}$ \\
\hline safety & $\begin{array}{l}\text { 1. the state of being safe and pro- } \\
\text { tected from danger or harm } \\
\text { 2. the state of not being dangerous } \\
\text { 3. a place where you are safe }\end{array}$ & $\begin{array}{l}\text { 1. the condition of being protected } \\
\text { from or unlikely to cause danger, } \\
\text { risk, or injury }\end{array}$ \\
\hline sagacity & $\begin{array}{l}\text { sagacious adj. } \\
\text { showing good judgement and un- } \\
\text { derstanding } \mathbf{S Y N} \text { wise } \\
\text { Derivative: sagacity }\end{array}$ & the quality of being sagacious \\
\hline sailing & $\begin{array}{l}\text { 1. the sport or activity of travelling } \\
\text { in a boat with sails } \\
\text { 2. one of the regular times that a } \\
\text { ship leaves a port }\end{array}$ & $\begin{array}{l}\text { the action of sailing in a ship or } \\
\text { boat } \\
\text { Subsense: a voyage made by a } \\
\text { ferry or cruise ship, especially ac- } \\
\text { cording to a planned schedule } \\
\text { Subsense: an act of beginning a } \\
\text { voyage or of leaving a harbour }\end{array}$ \\
\hline salesmanship & $\begin{array}{l}\text { skill in persuading people to buy } \\
\text { things }\end{array}$ & $\begin{array}{l}\text { salesman noun } \\
\text { a man whose job involves selling } \\
\text { or promoting commercial prod- } \\
\text { ucts, either in a shop or visiting lo- } \\
\text { cations to get orders } \\
\text { Derivative: salesmanship }\end{array}$ \\
\hline
\end{tabular}




\begin{tabular}{|c|c|c|}
\hline taboo & $\begin{array}{l}\text { 1. a cultural or religious custom } \\
\text { that does not allow people to do, } \\
\text { use or talk about a particular thing } \\
\text { as people find it offensive or } \\
\text { embarrassing } \\
\text { 2. a general agreement not to do } \\
\text { sth or talk about sth }\end{array}$ & $\begin{array}{l}\text { a social or religious custom pro- } \\
\text { hibiting or restricting a particular } \\
\text { practice or prohibiting association } \\
\text { with a particular person, place, or } \\
\text { thing. }\end{array}$ \\
\hline tact & $\begin{array}{l}\text { the ability to deal with difficult or } \\
\text { embarrassing situations carefully } \\
\text { and without doing or saying any- } \\
\text { thing that will annoy or upset other } \\
\text { people SYN sensitivity }\end{array}$ & $\begin{array}{l}\text { adroitness and sensitivity in deal- } \\
\text { ing with others or with difficult is- } \\
\text { sues }\end{array}$ \\
\hline tactic & $\begin{array}{l}\text { 1. the particular method you use to } \\
\text { achieve sth } \\
2 . \text { the art of moving soldiers and } \\
\text { military equipment around during } \\
\text { a battle or war in order to use them } \\
\text { in the most effective way - com- } \\
\text { pare strategy }\end{array}$ & $\begin{array}{l}\text { an action or strategy carefully } \\
\text { planned to achieve a specific end. } \\
\text { Subsense: (tactics) the art of } \\
\text { disposing armed forces in order of } \\
\text { battle and of organizing opera- } \\
\text { tions, especially during contact } \\
\text { with an enemy. Often contrasted } \\
\text { with STRATEGY }\end{array}$ \\
\hline tactlessness & $\begin{array}{l}\text { tactless adj. } \\
\text { saying or doing things that are } \\
\text { likely to annoy or to upset other } \\
\text { people SYN insensitive } \\
\text { Derivative: tactlessness }\end{array}$ & $\begin{array}{l}\text { tactless adj. } \\
\text { having or showing a lack of adroit- } \\
\text { ness and sensitivity in dealing with } \\
\text { others or with difficult issues } \\
\text { Derivative: tactlessness }\end{array}$ \\
\hline taint & $\begin{array}{l}\text { the effect of sth bad or unpleasant } \\
\text { that spoils the quality of } \mathrm{sb} / \mathrm{sth}\end{array}$ & $\begin{array}{l}\text { a trace of a bad or undesirable } \\
\text { quality or substance } \\
\text { Subsense: a thing whose influence } \\
\text { or effect is perceived as contami- } \\
\text { nating or undesirable } \\
\text { Subsense: an unpleasant smell }\end{array}$ \\
\hline ubiquity & $\begin{array}{l}\text { ubiquitous adj. } \\
\text { seeming to be everywhere or in } \\
\text { several places at the same time; } \\
\text { very common } \\
\text { Derivative: ubiquity }\end{array}$ & $\begin{array}{l}\text { ubiquitous adj. } \\
\text { present, appearing, or found eve- } \\
\text { rywhere } \\
\text { Derivative: ubiquity }\end{array}$ \\
\hline ultimate & $\begin{array}{l}\text { the best, most advanced, greatest, } \\
\text { etc. of its kind }\end{array}$ & $\begin{array}{l}\text { 1. (the ultimate) the best achiev- } \\
\text { able or imaginable of its kind } \\
\text { 2. a final or fundamental fact or } \\
\text { principle }\end{array}$ \\
\hline vacancy & $\begin{array}{l}\text { lack of interest or ideas SYN emp- } \\
\text { tiness }\end{array}$ & $\begin{array}{l}\text { emptiness of mind; lack of intelli- } \\
\text { gence or understanding. }\end{array}$ \\
\hline wackiness & $\begin{array}{l}\text { wacky adj. } \\
\text { funny or amusing in a slightly } \\
\text { crazy way SYN zany } \\
\text { NO wackiness }\end{array}$ & $\begin{array}{l}\text { wacky adj. } \\
\text { funny or amusing in a slightly odd } \\
\text { or peculiar way. } \\
\text { Derivative: wackiness }\end{array}$ \\
\hline
\end{tabular}




\begin{tabular}{lll}
\hline wager & $\begin{array}{l}\text { an arrangement to risk money on } \\
\text { the result of a particular event } \\
\text { SYN } \text { bet }\end{array}$ & more formal term for BET \\
\hline wakeboarding & $\begin{array}{l}\text { the sport of riding on a short wide } \\
\text { board called a wakeboard while } \\
\text { being pulled along through the wa- }\end{array}$ & $\begin{array}{l}\text { the sport o riding on a short, wide } \\
\text { board resembling a surfboard and } \\
\text { ter by a fast boat }\end{array}$ \\
& $\begin{array}{l}\text { performing acrobatic manoeuvres } \\
\text { while being towed behind a motor } \\
\text { boat }\end{array}$ \\
\hline
\end{tabular}

Table 4. The OALD7 and NODE definitions of abstract nouns used in the test.

\begin{tabular}{|c|c|c|}
\hline $\begin{array}{l}\text { Abstract } \\
\text { Noun }\end{array}$ & OALD7 & NODE \\
\hline nadir & $\begin{array}{l}\text { the worst moment of a particular } \\
\text { situation }\end{array}$ & $\begin{array}{l}\text { the lowest point in the fortunes of a } \\
\text { person or organization }\end{array}$ \\
\hline calamity & $\begin{array}{l}\text { an event that causes great damage to } \\
\text { people's lives, property, etc.; disas- } \\
\text { ter }\end{array}$ & $\begin{array}{l}\text { an event causing great and often } \\
\text { sudden damage or distress; a disas- } \\
\text { ter }\end{array}$ \\
\hline abandon & $\begin{array}{l}\text { an uncontrolled way of behaving } \\
\text { that shows that sb does not care } \\
\text { what other people think }\end{array}$ & $\begin{array}{l}\text { complete lack of inhibition or re- } \\
\text { straint }\end{array}$ \\
\hline gaiety & $\begin{array}{l}\text { the state of being cheerful and full } \\
\text { of fun }\end{array}$ & $\begin{array}{l}\text { the state or quality of being light- } \\
\text { hearted or cheerful }\end{array}$ \\
\hline camaraderie & $\begin{array}{l}\text { a feeling of friendship and trust } \\
\text { among people who work or spend a } \\
\text { lot of time together }\end{array}$ & $\begin{array}{l}\text { mutual trust and friendship among } \\
\text { people who spend a lot of time to- } \\
\text { gether }\end{array}$ \\
\hline panache & $\begin{array}{l}\text { the quality of being able to do } \\
\text { things in a confident and elegant } \\
\text { way that other people find attrac- } \\
\text { tive; flair, style }\end{array}$ & $\begin{array}{l}\text { flamboyant confidence of style or } \\
\text { manner }\end{array}$ \\
\hline sacrilege & $\begin{array}{l}\text { an act of treating a holy thing or } \\
\text { place without respect }\end{array}$ & $\begin{array}{l}\text { violation or misuse of what is re- } \\
\text { garded as sacred }\end{array}$ \\
\hline taint & $\begin{array}{l}\text { the effect of sth bad or unpleasant } \\
\text { that spoils the quality of sb/sth }\end{array}$ & $\begin{array}{l}\text { a trace of a bad or undesirable qual- } \\
\text { ity or substance }\end{array}$ \\
\hline racket & $\begin{array}{l}\text { a dishonest or illegal way of getting } \\
\text { money }\end{array}$ & $\begin{array}{l}\text { an illegal or dishonest scheme for } \\
\text { obtaining money }\end{array}$ \\
\hline abhorrence & $\begin{array}{l}\text { a feeling of strong hatred, especially } \\
\text { for moral reasons }\end{array}$ & $\begin{array}{l}\text { a feeling of revulsion; disgusted } \\
\text { loathing }\end{array}$ \\
\hline gallantry & courage, especially in a battle & $\begin{array}{l}\text { courageous behaviour, especially in } \\
\text { battle }\end{array}$ \\
\hline cakewalk & sth that is extremely easy to do & an absurdly or surprisingly easy task \\
\hline
\end{tabular}




\begin{tabular}{lll}
\hline damnation & $\begin{array}{l}\text { the state of being in hell; the act of } \\
\text { sending sb to hell }\end{array}$ & $\begin{array}{l}\text { condemnation to eternal punishment } \\
\text { in hell }\end{array}$ \\
\hline gall & $\begin{array}{l}\text { rude behaviour showing a lack of } \\
\text { respect that is surprising because the } \\
\text { person doing it is not embarrassed; } \\
\text { impudence }\end{array}$ & $\begin{array}{l}\text { bold, impudent behaviour } \\
\text { obeisance }\end{array}$ \\
& $\begin{array}{l}\text { respect for sb/sth or willingness to } \\
\text { obey sb }\end{array}$ & deferential respect \\
\hline vacancy & lack of interest or ideas; emptiness & $\begin{array}{l}\text { emptiness of mind; lack of intelli- } \\
\text { gence or understanding }\end{array}$ \\
\hline
\end{tabular}

Table 5. One of the versions of the test. (Version 1a.)

Instrukcja: Poniżej znajduje się 16 rzeczowników angielskich. Obok każdego z rzeczowników podana jest jego definicja słownikowa. Twoim zadaniem jest przeczytanie definicji i na ich podstawie napisanie w wykropkowanym miejscu jednowyrazowego polskiego odpowiednika dla każdego z angielskich rzeczowników.

\begin{tabular}{|c|c|c|c|c|}
\hline \multicolumn{2}{|c|}{ Przykład } & justice & the fair treatment of people & ....sprawiedliwość...... \\
\hline 1. & nadir & $\begin{array}{l}\text { the } v \\
\text { situa }\end{array}$ & $\begin{array}{l}\text { rst moment of a particular } \\
\text { on }\end{array}$ & ...... \\
\hline 2. & calamity & $\begin{array}{l}\text { an e } \\
\text { ple's }\end{array}$ & $\begin{array}{l}\text { nt that causes great damage to peo- } \\
\text { ives, property, etc.; disaster }\end{array}$ & \\
\hline 3. & abandon & $\begin{array}{l}\text { an u } \\
\text { shov } \\
\text { peop }\end{array}$ & $\begin{array}{l}\text { ontrolled way of behaving that } \\
\text { that sb does not care what other } \\
\text { think }\end{array}$ & \\
\hline 4. & gaiety & the $\mathrm{s}$ & te of being cheerful and full of fun & $\ldots$ \\
\hline 5. & camaraderie & $\begin{array}{l}\text { mutu } \\
\text { peop }\end{array}$ & $\begin{array}{l}\text { trust and friendship among } \\
\text { who spend a lot of time together }\end{array}$ & \\
\hline 6. & panache & $\begin{array}{l}\text { flam } \\
\text { man }\end{array}$ & $\begin{array}{l}\text { yant confidence of style or } \\
\text { r }\end{array}$ & \\
\hline 7. & sacrilege & $\begin{array}{l}\text { viola } \\
\text { sacre }\end{array}$ & on or misuse of what is regarded as & \\
\hline 8. & taint & $\begin{array}{l}\text { the e } \\
\text { spoil }\end{array}$ & $\begin{array}{l}\text { ect of sth bad or unpleasant that } \\
\text { the quality of } \mathrm{sb} / \mathrm{sth}\end{array}$ & \\
\hline 9. & racket & $\begin{array}{l}\text { a dis } \\
\text { mon }\end{array}$ & nest or illegal way of getting & \\
\hline 10. & abhorrence & a fee & ng of revulsion; disgusted loathing & \\
\hline 11. & gallantry & $\begin{array}{l}\text { cour } \\
\text { battl }\end{array}$ & ous behaviour, especially in & \\
\hline
\end{tabular}




\begin{tabular}{|c|c|c|c|}
\hline 12. & cakewalk & something that is extremely easy to do & \\
\hline 13. & damnation & $\begin{array}{l}\text { condemnation to eternal punishment in } \\
\text { hell }\end{array}$ & \\
\hline 14. & gall & bold, impudent behaviour & .. \\
\hline 15. & obeisance & $\begin{array}{l}\text { respect for } \mathrm{sb} / \mathrm{sth} \text { or willingness to obey } \\
\mathrm{sb}\end{array}$ & ….......... \\
\hline 16. & vacancy & $\begin{array}{l}\text { emptiness of mind; lack of intelligence or } \\
\text { understanding }\end{array}$ & \\
\hline
\end{tabular}

Table 6. Possible Polish equivalents.

\begin{tabular}{|l|l|l|}
\hline & English abstract nouns & Possibile correct Polish equivalent \\
\hline 1. & calamity & klęska, katastrofa, nieszczęście \\
\hline 2. & gallantry & waleczność, męstwo, odwaga \\
\hline 3. & abandon & zapamiętanie, pasja, żywiołowość \\
\hline 4. & damnation & potępienie \\
\hline 5. & gaiety & wesołość, radość \\
\hline 6. & sacrilege & świętokradztwo, profanacja \\
\hline 7. & nadir & dno \\
\hline 8. & gall & czelność, tupet \\
\hline 9. & taint & piętno, zmaza, skaza \\
\hline 10. & vacancy & pustka, bezmyślność \\
\hline 11. & racket & przekręt, oszustwo, kant \\
\hline 12. & panache & polot, rozmach, szyk, styl \\
\hline 13. & obeisance & hołd, respekt, posłuszeństwo \\
\hline 14. & camaraderie & koleżeństwo \\
\hline 15. & cakewalk & łatwizna, prościzna \\
\hline 16. & abhorrence & odraza, wstręt \\
\hline
\end{tabular}


Table 7. The distribution of correct equivalents, correct equivalents of nouns already known by the subjects, lack of equivalents and incorrect equivalents.

\begin{tabular}{|c|c|c|c|c|c|}
\hline NODE & $\begin{array}{c}\text { correct } \\
\text { equivalent }\end{array}$ & $\begin{array}{c}\text { correct but } \\
\text { known }\end{array}$ & $\begin{array}{c}\text { lack of } \\
\text { equivalent }\end{array}$ & $\begin{array}{c}\text { incorrect } \\
\text { equivalent }\end{array}$ & TOTAL \\
\hline nadir & 4 & 0 & 11 & 15 & 30 \\
\hline calamity & 26 & 0 & 0 & 4 & 30 \\
\hline abandon & 0 & 0 & 2 & 28 & 30 \\
\hline gaiety & 10 & 5 & 2 & 13 & 30 \\
\hline camaraderie & 15 & 0 & 1 & 14 & 30 \\
\hline panache & 2 & 0 & 8 & 20 & 30 \\
\hline sacrilege & 18 & 1 & 3 & 8 & 30 \\
\hline taint & 10 & 0 & 9 & 11 & 30 \\
\hline racket & 18 & 0 & 1 & 11 & 30 \\
\hline abhorrence & 14 & 0 & 7 & 9 & 30 \\
\hline gallantry & 19 & 1 & 2 & 8 & 30 \\
\hline cakewalk & 13 & 1 & 1 & 15 & 30 \\
\hline damnation & 10 & 1 & 4 & 15 & 30 \\
\hline gall & 1 & 0 & 3 & 26 & 30 \\
\hline obeisance & 13 & 0 & 5 & 12 & 30 \\
\hline vacancy & 8 & 1 & 0 & 21 & 30 \\
\hline TOTAL & $\begin{array}{c}181 \\
(37.70 \%) \\
\end{array}$ & $\begin{array}{c}10 \\
(2.08 \%) \\
\end{array}$ & $\begin{array}{c}59 \\
(12.29 \%) \\
\end{array}$ & $\begin{array}{c}230 \\
(47.91 \%) \\
\end{array}$ & $\begin{array}{c}480 \\
(100 \%) \\
\end{array}$ \\
\hline OALD7 & $\begin{array}{c}\text { correct } \\
\text { equivalent }\end{array}$ & $\begin{array}{c}\text { correct but } \\
\text { known }\end{array}$ & $\begin{array}{c}\text { lack of } \\
\text { equivalent }\end{array}$ & $\begin{array}{l}\text { incorrect } \\
\text { equivalent }\end{array}$ & TOTAL \\
\hline nadir & 5 & 0 & 6 & 19 & 30 \\
\hline calamity & 24 & 0 & 0 & 6 & 30 \\
\hline abandon & 0 & 0 & 0 & 30 & 30 \\
\hline gaiety & 17 & 1 & 0 & 12 & 30 \\
\hline camaraderie & 10 & 2 & 2 & 16 & 30 \\
\hline panache & 10 & 0 & 8 & 12 & 30 \\
\hline sacrilege & 24 & 1 & 2 & 3 & 30 \\
\hline taint & 8 & 0 & 5 & 17 & 30 \\
\hline racket & 15 & 0 & 2 & 13 & 30 \\
\hline abhorrence & 14 & 0 & 6 & 10 & 30 \\
\hline gallantry & 21 & 0 & 0 & 9 & 30 \\
\hline cakewalk & 23 & 0 & 0 & 7 & 30 \\
\hline damnation & 6 & 5 & 4 & 15 & 30 \\
\hline gall & 0 & 0 & 5 & 25 & 30 \\
\hline obeisance & 19 & 1 & 1 & 9 & 30 \\
\hline vacancy & 19 & 2 & 2 & 7 & 30 \\
\hline TOTAL & $\begin{array}{c}215 \\
(44.79 \%)\end{array}$ & $\begin{array}{c}12 \\
(2.5 \%)\end{array}$ & $\begin{array}{c}43 \\
(8.95 \%)\end{array}$ & $\begin{array}{c}210 \\
(43,75 \%)\end{array}$ & $\begin{array}{c}480 \\
(100 \%)\end{array}$ \\
\hline
\end{tabular}


Address correspondence to:

Marta Grochocka

School of English, Adam Mickiewicz University

al. Niepodległości 4

61-874 Poznań

Poland

martag@ifa.amu.edu.pl 